\title{
PLANT PARASITIC NEMATODES ASSOCIATED WITH Annona squamosa L.
}

\author{
John Dhaniel M. Bumanglag ${ }^{1}$, Michael David E. Soliman ${ }^{1}$, Lourdes V. Alvarez ${ }^{1}$, \\ Carmelita P. Mapanao ${ }^{1}$, Arnel O. Rendon ${ }^{1}$, Leilidyn Y. Zurbano ${ }^{2}$
}

${ }^{1}$ Department of Biology, College of Science, Polytechnic University of the Philippines, Sta. Mesa, Manila, Philippines

${ }^{2}$ Agribusiness Department, Polytechnic University of the Philippines, Lopez, Quezon, Philippines

Received - September 01, 2020; Revision - November 22, 2020; Accepted - December 15, 2020

Available Online - December 30, 2020

DOI: http://dx.doi.org/10.18006/2020.8(6).818.827

\section{KEYWORDS \\ Annona squamosa \\ Plant Parasitic Nematodes \\ Rotylenchus \\ Criconemoides \\ Meloidogyne}

\begin{abstract}
The current study was conducted from December 2018 to January 2019 to identify plant-parasitic nematodes (PPNs) associated with A. squamosa in Rizal Province, Philippines. A total of 10 soil and root samples were collected from the surveyed plants. Nematodes from the collected soil samples were extracted using the modified Baermann tray method while root nematodes were extracted using $\mathrm{H}_{2} \mathrm{O}_{2}$ incubation. Results of the study revealed the presence of Meloidogyne, Rotylenchulus, and Criconemoides PPNs genera from the roots and soil samples. The study revealed that the number of nematodes associated with A. squamosa is not enough to cause infestation and damage. Further, various environmental factors such as moisture and potassium content of the soil, temperature, and $\mathrm{pH}$ make the conditions unfavorable for the proliferation of plant-parasitic nematodes in the study area.
\end{abstract}

* Corresponding author

E-mail: leydenzurbano@yahoo.com (Leilidyn Y.Zurbano)

Peer review under responsibility of Journal of Experimental Biology and Agricultural Sciences.

Production and Hosting by Horizon Publisher India [HPI] (http://www.horizonpublisherindia.in/).

All rights reserved.
All the articles published by Journal of Experimental Biology and Agricultural Sciences are licensed under a Creative Commons Attribution-NonCommercial 4.0 International License Based on a work at www.jebas.org.

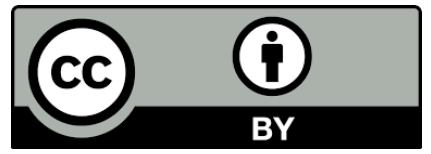




\section{Introduction}

Annona squamosa L. locally known as Atis is a fruit tree, belongs to the family Annonaceae. It is an evergreen plant mainly located in tropical and subtropical regions, including the Philippines (Narwade \& Aher, 2019). It has a long history of ethnomedicinal uses such as tonic, apophlegmatisant, abortient, heart sedative, anticancer, antioxidant, antidiabetic, antihypertensive, hepatoprotective, antiparasitic, antimalarial, insecticidal, microbicidal, and molluscicidal activities (Sharma \& Goray, 2009; Saha, 2011; Narwade \& Aher, 2019). The fruits are also extensively used to prepare desserts and beverages.

Different crops have different parasites and some of which are the plant parasitic nematodes (PPNs). Nematodes are microscopic organisms that are considered as one of the pests of different crops. These are considered to be very diverse since many occupy all parts of the earth. They are also very hard to identify since they are very minute. In a global context, there is increasing demand for nematode taxonomists to assess community structure concerning soil function, to develop new tools for agronomic management, and to address quarantine regulations.

Plant parasitic nematodes are among the most important agricultural pests and cause serious crop losses worldwide. Nematodes mostly inhabit the soil and attack the underground parts of the plants that's why the management of nematodes is more difficult than that of other pests. Chemical nematicides are effective, easy to apply, and show rapid effects, but they have begun to be removed from the market in some developed countries because of public health and environmental safety concerns (Tian et al., 2007).

The plant parasitic nematodes associated with A. squamosa are not yet identified. Hence, this study was formulated with the aim of Identify plant parasitic nematodes genera associated with the roots and soil of A. squamosa. This identification of PPN was completely based on their morphological characteristics (size, shape, and body structure). Further, the effect of soil texture and its nutritive value concerning $\mathrm{pH}$, nitrogen, phosphorus, and potassium on plant parasitic nematode occurrence was also studied in the present study. The morphological identification of the plant parasitic nematodes associated with A. squamosa can significantly contribute to the field of agriculture research because these plant parasitic nematodes could destroy the crops and affect the yield will be identified. Thus, this study could lead to proper management practices in controlling plant parasitic nematodes associated with $A$. squamosa.

\section{Materials and Methods}

\subsection{Description of the Area of Study}

The roots and soil sample collection of A. squamosa was carried out from the Sarian Farm, located at Teresa, Rizal, Philippines.
The farm specializes in propagating superior varieties of fruit trees and some selected crops. In the area of collection, some trees of $A$. squamosa exhibited signs of infestation such as wilting and chlorosis of leaves.

\subsection{Sample Size and Sampling Technique}

Five A. squamosa plants that are showing nematode infestation symptoms such as chlorosis and wilting of leaves were selected for the collection of the roots and soil subsamples (Xavier-Mis, 2016). Among these, three were mature and the other two plants were at the seedlings stage. The collection of soil samples was carried out around the drip line of each tree by removing $2 \mathrm{~cm}$ of the above soil using a trowel and probing the soil with a depth of $15-30 \mathrm{~cm}$ using a soil auger. Ten soil subsamples were collected from each tree, mixed, and put in zip lock bags. The fibrous roots were collected within the depth of 15-30 cm using a trowel around the drip line of each tree. These subsamples were stored together in a plastic bag with a seal, together with a little amount of soil to maintain its freshness (Abawi \& Gugino, 2007; Xavier-Mis, 2016). After the collection, the plastic bags with samples were labeled clearly and systematically with the sample number or reference using a permanent marker and placed in a cool box. It was put in a cool shaded area since nematodes are very sensitive and perishable, thus, appropriate care must be taken to keep them in good condition (Nambiar \& Wainer, 2011).

\subsection{Nematode Extraction from Soil Samples using the Baermann Tray Method}

For each soil sample, five replicates were prepared. One hundred cc soil samples were put in a wire mesh with 2 ply tissue papers. After that, it was placed in a bowl with water. The bowl was covered with plastic to reduce the evaporation of water and was left for 3 days. After incubation, the suspension was collected and poured in stacks of sieves which are the 80 , 325 , and 400 mesh from top to bottom. Afterward, the soil nematode suspension was collected from the terminal sieve by concentrating the particles on one side and carefully poured into the glass vial. Then, nematodes were checked using the dissecting microscope (Ferris et al., 2004)

\subsection{Nematode Extraction from Root Samples using Incubation in $\mathrm{H}_{2} \mathrm{O} 2$}

The root samples were cut into pieces and were placed in a bottle with $100 \mathrm{ml}$ of $1 \%$ of $\mathrm{H}_{2} \mathrm{O}_{2}$ and covered tightly. Then, it was incubated for 48 hours at room temperature. Afterward, all the solutions were poured on 225 mesh over 400 mesh sieves and was rinsed thoroughly. Then, the nematode suspension from the terminal sieve was collected and used for identification (Ferris et al., 2004; Coyne et al., 2007) 


\subsection{Preparation of Fixative, Mounting and Fixation}

For fixing isolated nematode species, a fixative medium was prepared by mixing $100 \mathrm{~mL}$ of 40 percent formalin, $10 \mathrm{~mL}$ of glycerol, and $450 \mathrm{~mL}$ distilled water. This setup was done twice because the other one was used in producing the mounting medium. Once mixing is done, one of the finished solutions was poured into an amber bottle for storage. The remaining setup was continued by adding $560 \mathrm{~mL}$ distilled water to produce a $1 \mathrm{X}$ strength formalin-glycerol which was later used as a mounting medium. After mixing, it was also poured in a $1 \mathrm{~L}$ amber bottle for storage to avoid any reactions (Abawi \& Gugino, 2007; Coyne et al., 2007).

For nematode fixation, nematode suspension was collected in a vial and these vials were immersed in a water bath for 40 seconds. The vials were removed and an equal amount of $2 x$ fixative solution was added to the nematode suspensions. The vials were covered and left for 24 hours (Abawi \& Gugino, 2007; Coyne et al., 2007).

Before mounting, the glass slides were placed in a ringer to make an even thickness ring to avoid smashing the nematodes to be mounted using nail polish. The nail polish ring was air-dried for it to harden before adding the mounting medium. When the nail polish ring hardens, a drop of mounting medium was placed in the center of the nail polish ring. On the other hand, the fixed nematode suspension was poured into an agar plate and it was examined under a compound microscope to find the target nematode using a low magnification and verify it at high magnification. The magnification was shifted back to the low to pick a nematode (Abawi \& Gugino, 2007; Coyne et al., 2007).

Nematodes were picked with the help of a nematode picker, for this the medium surrounding the nematode was agitated so that the nematode can be picked easily. The picked nematodes were placed at the center of the drop of mounting medium of the glass slide After ensuring the mounted nematode, it was covered using a coverslip and sealed with the nail polish. After sealing, it was labeled on both ends using slide labels with its identity, and the number of mounted specimen. On the other end, it was labeled indicating the name of the collector, plant, and the place of its collection (Abawi \& Gugino, 2007; Coyne et al., 2007).

\subsection{Morphological Identification}

The morphological identification of plant parasitic nematodes associated with $A$. squamosa was done by using the scanner, LPO, HPO, and the oil immersion objective of the Euromex light microscope. The observations were recorded and photographs 100x were also taken. The "Identification Key for Agriculturally Important Plant-parasitic Nematodes Prepared for the International
Nematode Diagnosis and Identification Course", Eskisehir, Turkey (2012), A Manual for Nematology (Mengistu et al., (2013) and the "Plant Parasitic Nematodes in Subtropical and Tropical Agriculture"(Luc et al.,2005) was used for the identification of these plant parasitic nematodes. Expert advice was also done by Mr. Romnick A. Latina, an expert in nematology and a professor at the University of the Philippines, Los Baños.

\subsection{Plant Parasitic Nematode Population Count}

A clear plastic dish with grids imprinted on the bottom was used as the counting dish. The plant parasitic nematodes solution was transferred into the counting dish carefully, avoiding splashing. The nematodes present were counted in the total suspension volume in the counting dish in a systematic way following the gridlines on the dish. The counted PPN's suspension was returned on the vial. The procedure was repeated for all the suspension samples (Coyne et al., 2007).

\subsection{Soil Analysis}

The soil sample was brought to the Bureau of Soils and Water Management in Quezon City for the analysis of its $\mathrm{pH}$, nitrogen, phosphorus, and potassium content of the soil. Soil samples were analyzed using the colorimetric method for $\mathrm{N}, \mathrm{P}$, and $\mathrm{K}$ determination while $\mathrm{pH}$ was analyzed using a $\mathrm{pH}$ meter (Regalado \& Dela Cruz, 2016).

\section{Results and Discussion}

\subsection{Morphological characteristics of plant-parasitic nematodes}

Three genera of the nematodes were identified from the soil and root samples of A. squamosa. The major identified genera are Criconemoides (ring nematode), Meloidogyne (root-knot nematode), and Rotylenchulus (reniform nematode). Further, nematodes species of the family Criconematidae feed ectoparasitically on common plant hosts such as grasses and woody perennial plant roots, wherein some are at root tips, others in more mature regions of the root, including areas where the root surface is disrupted by lateral root emergence

In this study, only female species were found due to the rarity of the male species, these results are in agreement with previous findings (Jaffee et al., 1989; Ferris et al., 2004). The entire female species that belong to Criconematidae is stout, sausage-like shape to cylindrical, with a length that ranges from $104.57 \mu \mathrm{m}$ to 107.86 $\mu \mathrm{m}$ long and a width of $25.86 \mu \mathrm{m}$ and is ventrally arcuate after heat relaxation, which can be seen in Figure 1A and 1D. This characteristic makes it distinguishable from any other plant parasitic nematodes. Criconemoides female species has a retrorse annulus with finely crenate edges, scales, or spines which is seen in all the figures 1A-D. The stylet is robust with an anchor-shaped 


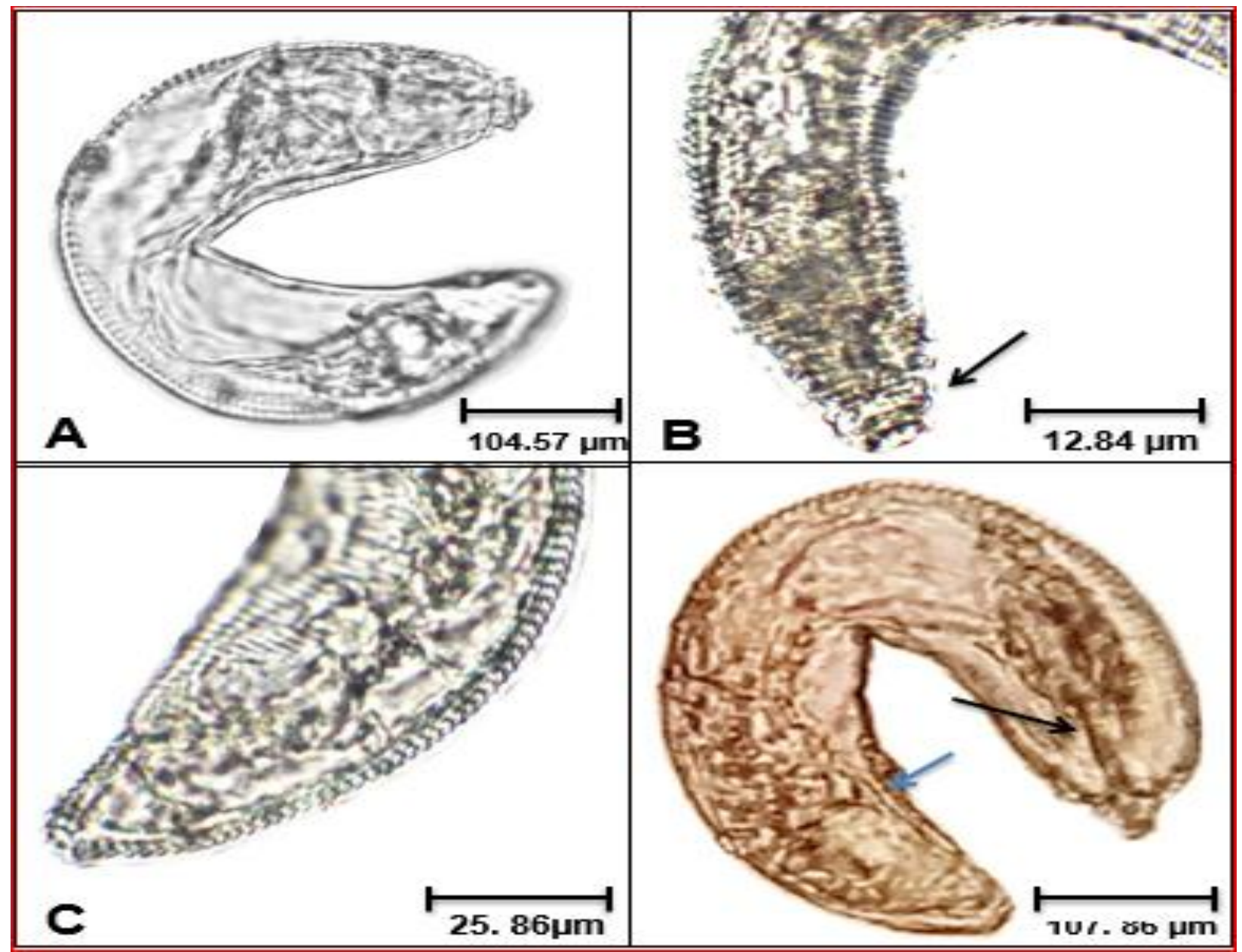

Figure 1 Criconemoides observed under OIO. (A and D) entire female; (B) female labial region; (C) posterior end of the female; (D) entire female showing the vulva (blue arrow) and stylet (black arrow)

knob which is greatly seen in Figure 1D. It has also a long stylet which allows penetration and feeding on cells, several layers deep at the root tip or in the root cortex. Their labial area is about 12.84 $\mu \mathrm{m}$ and is not well separated from the rest of the body which is marked by one or two thinner annules. It is also variously shaped and its sclerotization is strong, as seen in Figure 1B. Their esophagus is not visible due to thick annulations. The vulva is located posterior with one genital tract, extending anteriorly (Hoffman, 1973; Ferris et al., 2004; Olson et al., 2017).

The Heteroderidae family is a family of plant-parasitic nematodes that are composed of sedentary obligate parasites of roots which leads to the formation of galls in roots in some cases. Among the genera that belong in this family, only juvenile Meloidogyne was found which was reported as the most common and destructive plant-parasitic nematode that greatly influence both the quality of the crop and crop yield (Bellafiore et al., 2015)
The juvenile Meloidogyne, as seen in Figure 2A is vermiform in shape and is about $388.95 \mu \mathrm{m}$ in length and is $15.907 \mu \mathrm{m}$ in width, as seen in Figure 2D. The anterior region, as seen in figure $3 \mathrm{D}$, clearly shows the metacorpus, which is pointed by the black arrow, is one of the distinguishing characteristics of plantparasitic nematodes from free-living nematodes, and the nerve ring which is pointed by the yellow arrow. The stylet of these juveniles is short and moderately sclerotized which is about $13.161 \mu \mathrm{m}$, and their labial region skeleton is weakly sclerotized (Figure 2B). The tail of the juvenile Meloidogyne species is long, conical-shaped with an irregular tip in outline, as seen in Figure 3C, is about $55.29 \mu \mathrm{m}$ and is internally clear. However, mature females are not observed in the study because the only passive method was used to extract these plant parasitic nematodes which are only capable of extracting motile plantparasitic nematodes to avoid the risk of sample destruction (Hunt et al., 2005). 


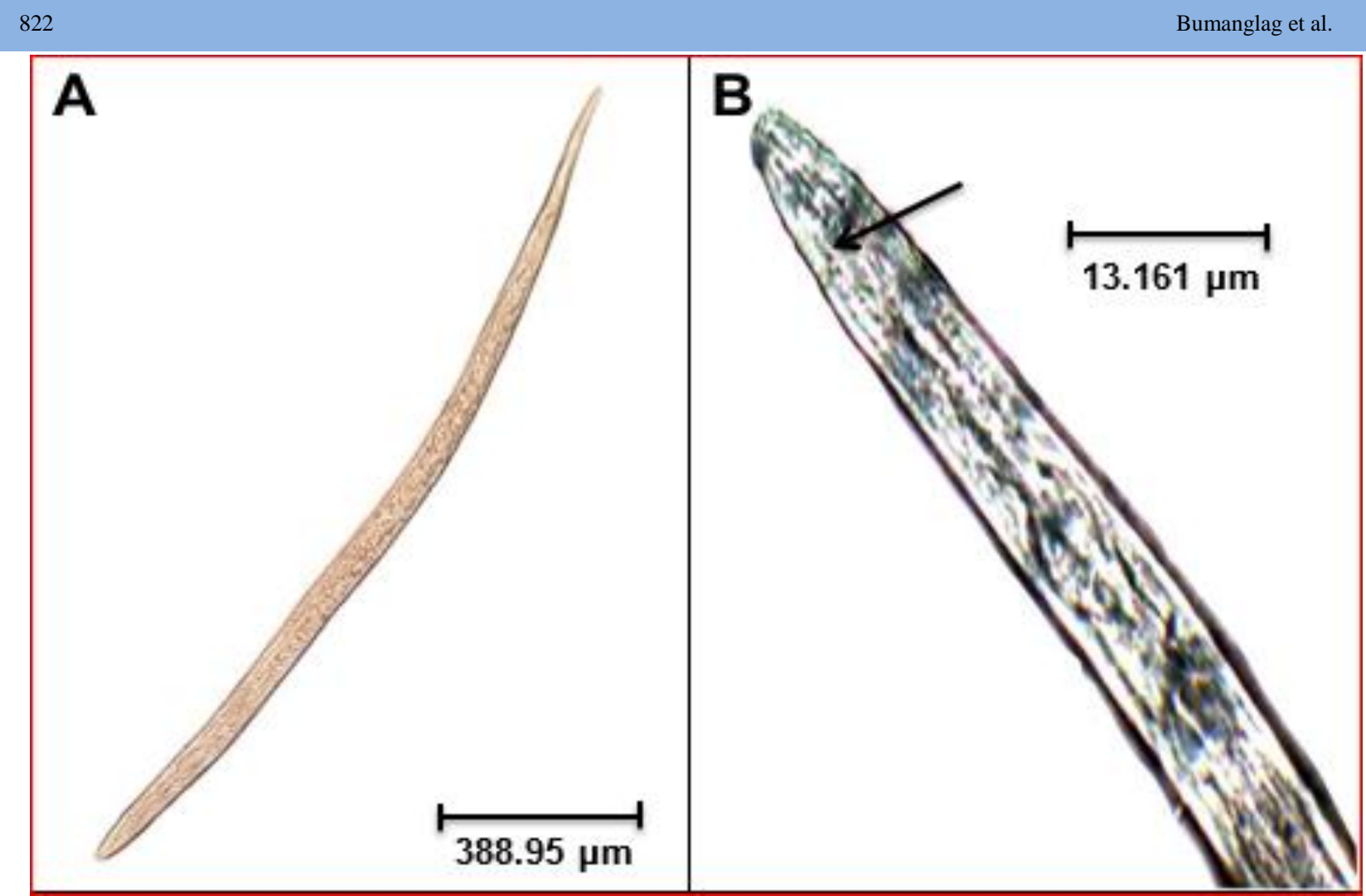

Figure 2. Meloidogyne species observed under HPO (A) and OIO (B). (A) Entire juvenile; (B) head region showing the stylet (black arrow)

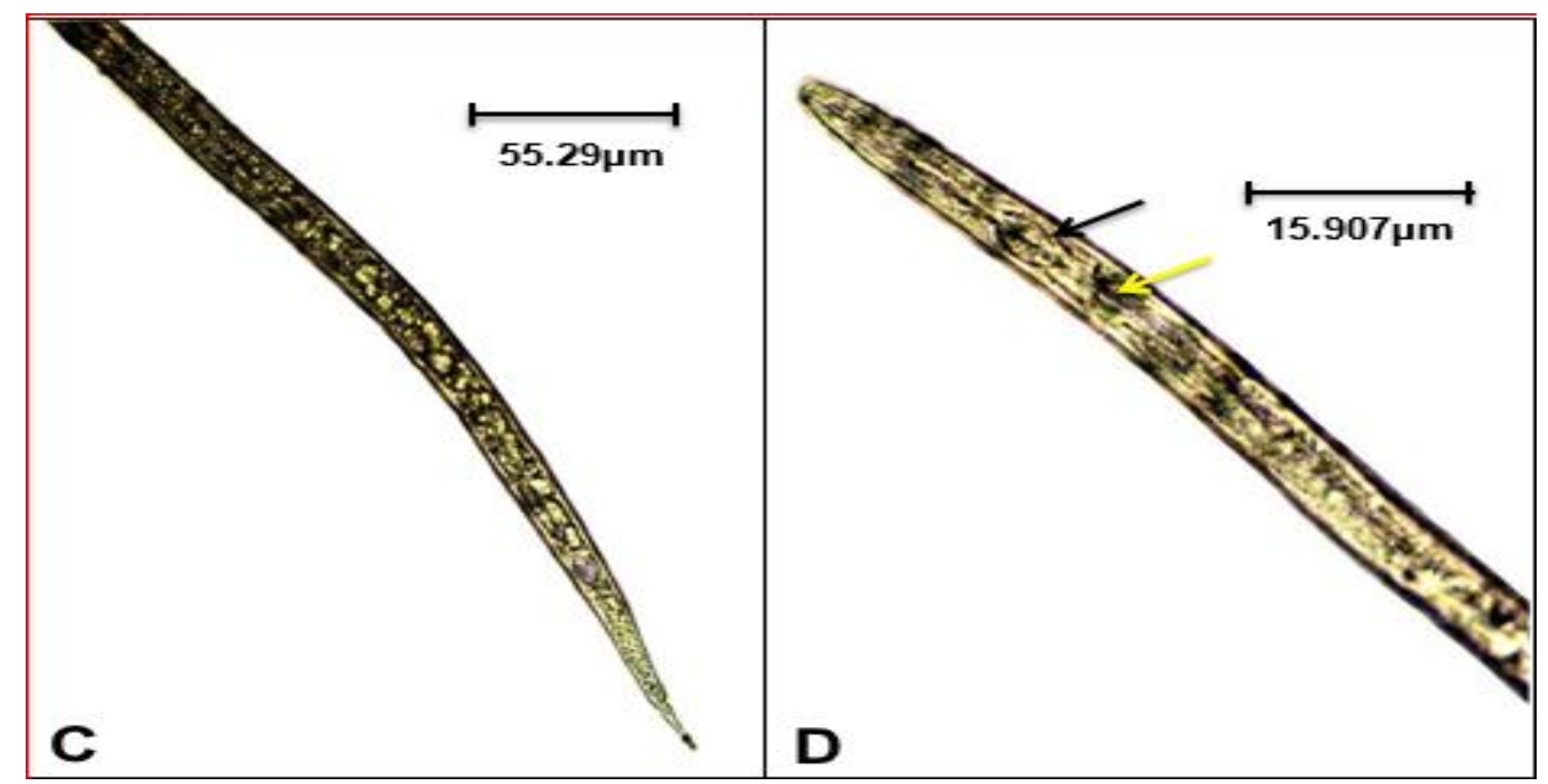

Figure 3 Meloidogyne species observed under HPO (C, D). (C) posterior part of the juvenile; (D) Anterior part of the juvenile showing metacorpus (black arrow) and nerve ring (yellow arrow) 


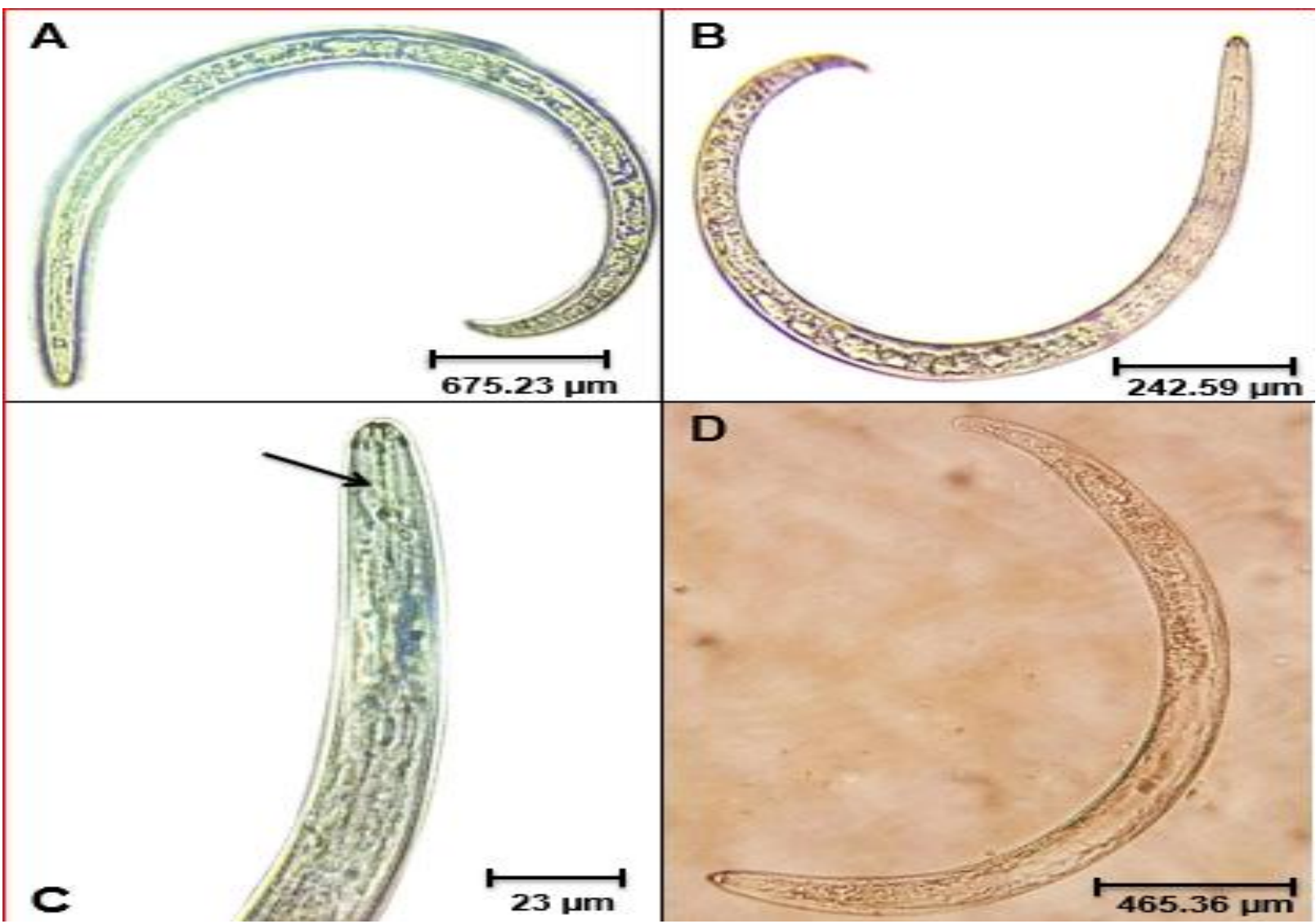

Figure 4. Rotylenchulus observed under HPO (A,B,D) and OIO (C). (A-B) entire immature female;

(C) head region showing the stylet (black arrow); (D) entire male

The family Hoplolaimidae is a family of plant-parasitic nematodes that are considered as obligate higher plant parasites with a migratory ecto-endoparasitic habit, and sometimes semi-endosedentary parasites. Members of the family are vermiform-shaped nematodes which turn into kidney-shaped upon adulthood (Ferris et al., 2004; Subbotin et al., 2015). In this study, only male species and immature vermiform females were found.

The immature female of Rotylenchulus spp., as seen in the Figures 4A and $4 \mathrm{~B}$, has a vermiform and small body with a length that is about $242.59 \mu \mathrm{m}$ to $675.23 \mu \mathrm{m}$, and a width of about $23.75 \mu \mathrm{m}$ to 11.51 $\mu \mathrm{m}$, respectively, which are ventrally arcuate. The labial region is continuous with body contour which is rounded, striated and has a rounded outline and their labial sclerotization is medium (Figure 4C). This figure also shows the stylet, which has a length of $23 \mu \mathrm{m}$ and is classified as medium strength, with rounded basal knobs. The esophagus is not visible in all the Rotylenchulus $s p$. that has been observed. Figure 5G shows the tail of an immature female with a length of $109.46 \mu \mathrm{m}$, that is conoid with rounded terminus and the vulva (red arrow) which is situated posteriorly with not protuberant vulval lips and has two genital tracts, each with a double flexure. Figure 5.2E and 5F show the entire juvenile which resembles an immature female, but shorter and lacking vulva and genital tracts. It has a length of $207.44 \mu \mathrm{m}$ and a width of 11.55 $\mu \mathrm{m}$. The tail has a length of $34.22 \mu \mathrm{m}$. Figure 4D shows the entire male with a length of $465.36 \mu \mathrm{m}$ and a width of $30.42 \mu \mathrm{m}$, which also has a vermiform body. The labial sclerotization is also medium developed. The stylet and esophagus of the male are not visible. Figure $5 \mathrm{H}$ shows their spicule that is located ventrally in the tail and is curved. The tail of the male is pointed (Eisenback, 2002; Nakasono, 2004; Hunt et al.,2005).

\subsection{Total count of plant-parasitic nematodes of A.squamosa}

Table 1 shows the population count of plant parasitic nematodes found in both soils and root samples. In soil samples, Criconemoides had the highest number (51), followed by Meloidogyne (12) and Rotylenchulus(2). Further, in roots samples, Criconemoides also had the highest number (42), followed by Rotylenchulus (13)and Meloidogyne (4). 


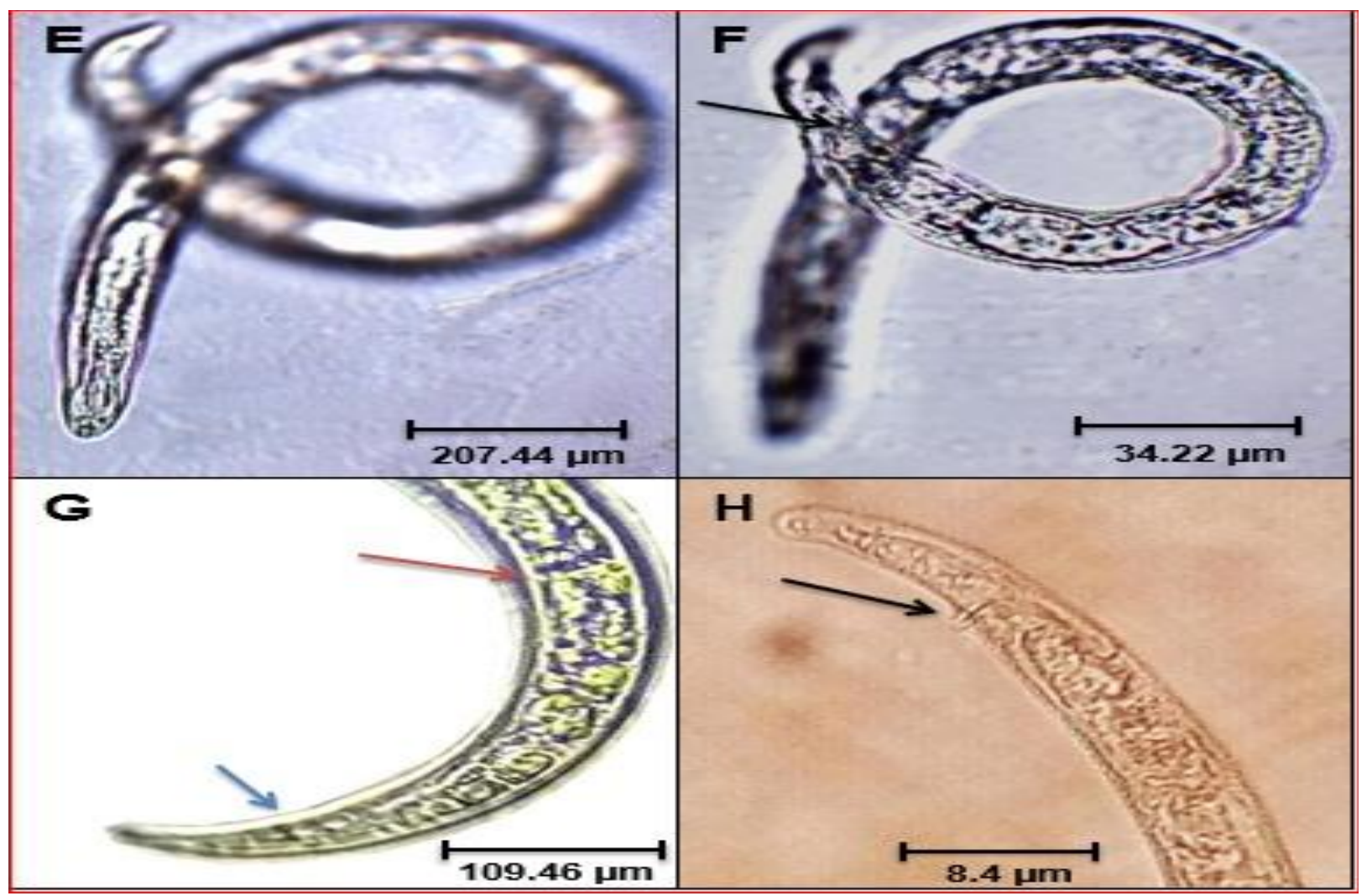

Figure 5 Rotylenchulus observed under OIO (E,F) and HPO (G,H). (E) entire juvenile; (F) entire juvenile showing the tail; (G) posterior part of the immature female showing the vulva (red arrow) and anus (blue arrow); (H) posterior end of male showing the spicule (black arrow).

Table 1 Total count of the genus of plant-parasitic nematodes found associated with the soil and roots of $A$. squamosa

\begin{tabular}{|c|ccc|}
\hline NEMATODE GENERA & $\begin{array}{c}\text { COUNT IN SOIL SAMPLES } \\
(6.9 \mathrm{pH})\end{array}$ & $\begin{array}{c}\text { COUNT IN ROOT } \\
\text { SAMPLES }\end{array}$ & TOTAL COUNT \\
\hline Criconemoides & 51 & 42 & $\mathbf{9 3}$ \\
\hline Meloidogyne spp. & 12 & 4 & $\mathbf{1 6}$ \\
\hline Rotylenchulus spp. & 2 & 13 & $\mathbf{1 5}$ \\
\hline
\end{tabular}

Plant-parasitic nematodes are counted to identify the groupings and number of PPNs with the crop growing in the area and the soil characteristics. Also, this is an attempt to evaluate the occurrence and economic importance of these plant-parasitic nematodes associated with A. squamosa (Subbotin et al., 2015). As reported by Zehr et al. (1986), there are around 250 Criconemellas/100 $\mathrm{cc}$ of soil on its initial count and around PPN's in $100 \mathrm{cc}$ of soil (Miller, 1980) which create damages on crops. These previous results are contradictory to the findings of the current study, where PPN's were found less than 100/100 cc.

\subsection{Texture, pH, Nitrogen, Phosphorus, Potassium Content of Soil in the Sampling Site}

The collected samples from the sampling site in Teresa, Rizal were reddish-brown and classified as silty clay due to its creamy and soft texture. These soils are considered marginal for agriculture because this type of soil is acidic, which has low cation exchange capacity, and low water holding capacity (Needelman, 2013). In the current study, three soil samples were sent for analysis to the Bureau of Soils and Water Management, among these, the first sample was collected from this study site while samples 2 and 3 were from the study and used as a reference for the comparison of soil sample characteristics (Table 2). All three samples were acidic soils, characteristics for all the soils in the whole province of Rizal (Pouyat et al., 2007; Carating et al., 2014; Carpio et al., 2017;).

Nutrients in soil play a very important role not just in plants but also in other living organisms. As seen in Table 2 sample 1 has moderately low nitrogen content, sample 2 has low nitrogen content while sample 3 has high nitrogen content. The low to a 
Table 2 Soil analysis of the soil samples from Sarian Farm, Teresa, Rizal, Philippines. December 2018.

\begin{tabular}{|ccccccc|}
\hline Soil Sample & pH & Nitrogen & $\begin{array}{c}\text { Test Results } \\
\text { Phosphorus }\end{array}$ & Potassium & Texture Feel \\
\hline 1 & 6.9 & Moderately low & High & Sufficient & Heavy \\
\hline 2 & 5.0 & Low & Moderately high & Sufficient & Light \\
\hline 3 & 6.5 & High & Medium & Sufficient & Heavy \\
\hline
\end{tabular}

Table 3 Standard soil data in Teresa, Rizal, Philippines

\begin{tabular}{|ccccccc|}
\hline Soil Sample & pH & Test Results & Potassium & Texture Feel \\
\hline Standard & 7 & High & Moderately High & Sufficient & Light \\
\hline
\end{tabular}

moderately low level of nitrogen in soil indicates that the soil is low in organic content and acidic because the change in nitrogen indicates changes in soil pH (Lamb et al., 2014). The high nitrogen level in acidic soil, on the other hand, might indicate that it was recently added with fertilizers and there is a high amount of other nutrients such as phosphorus and potassium. In terms of phosphorus contents, the medium to high levels of phosphorus is because of the animal manures which were reported from the sampling site. According to Liu et al. (2013), animal manures are a rich source of phosphorus which might greatly affect the content of the acidic soil from the sampling site. In terms of sufficient levels of potassium in all three soil samples, it can be explained by the presence of clay particles in the samples which traps the small molecules of potassium. It is also sufficient in soil because small clay and humus particles which can be seen in the sampling site and the samples themselves develop negative electrical charge particles attract positively charged ions, or cations, which include potassium (Stack, 2016). In terms of the texture of the soil samples, it just depends on the location inside the sampling site, where some have wet silt clay and some have dry silt clay which is a characteristic of a soil that can be found in the Teresa series in Rizal province (Carating et al., 2014; Carpio et al., 2017;).

As compared to the sampling site soil (Table 3), the standard soil has a neutral $\mathrm{pH}$ of 7 , high nitrogen, moderately high phosphorus, sufficient potassium content and a light texture in the feeling method (Carating et al., 2014; Carpio et al., 2017).

\subsection{Association between the soil characteristics and plant- parasitic nematodes occurrence}

Results of the study suggested that for the genus Criconemoides, moisture fluctuations are said to be a major limiting factor. The reduction in the numbers of the genus under this family has been observed due to the rapid changes in moisture levels due to the higher temperatures. The optimum temperature for reproduction may vary with the host plant, as well as the genus under this family, evidence indicates that the range of 22 to $26^{\circ} \mathrm{C}$ is the best.
The $\mathrm{pH}$ of the soil sample is 6.9. It has been reported that $\mathrm{pH} 7.0$ was significantly better for population increase. It has also been reported that lighter sandy soils are better than heavier clay soils in supporting nematode populations. Criconemoides had the highest count among the other plant parasitic nematodes in the soil samples. However, comparing with the number of Criconemoides reported in other studies, the count is still low since they are not in their optimum environment which should be in neutral $\mathrm{pH}$ with lower temperature soils (Chalanska \& Labanowski,2014).

The potassium is required for turgor build up in plants and long distance transport of water. Root-knot nematodes like Meloidogyne spp. disrupt the xylem and phloem of their hosts which compromised the transport of water and nutrients. In that case, the root-knot nematodes will be lower in potassium deficit plants. Sandy type of soil could help increase Meloidogyne population since there are macropores that allow the nematodes to penetrate easily. The soil sample in this study has sufficient potassium which gives rise to the occurrence of nematodes, but because of the type of soil which was heavy in texture, Meloidogyne spp., has relatively low frequency in terms of their population (Warner, 2009).

The environmental factors, particularly the temperature, influence the juvenile Rotylenchulus spp. development (Nakasano, 2004). Plant parasitic nematodes are generally sensitive to heat. The juvenile Rotylenchulus spp. severely suffers from high temperature $\left(33{ }^{\circ} \mathrm{C}\right)$ so its juveniles could not develop to young females or males in water medium and soil. The temperature at the sampling site was $31{ }^{\circ} \mathrm{C}$ and only one juvenile Rotylenchulus spp. and 14 immature females and males were observed. This might be a reason for less population of this plant parasitic nematodes. The $\mathrm{pH}$ of the soil sample is 6.9. It is said that $\mathrm{pH}$ also has a negligible effect on juvenile development except for the extremely low $\mathrm{pH}$ like 2.9. The type of soil is silty clay which has a heavy texture. Rotylenchulus spp. is significantly influenced by soil texture wherein they exhibit a decrease in population in increasing median soil particle size. However, it could be noted that the ability of the 
nematodes to reproduce and inflict damage was not affected by the soil and plant's nutrient status. The phosphorus harms the nematode reproduction while it has a positive effect on the plant growth (Nakasano, 2004; Warner, 2009)

\section{Conclusions and Recommendations}

The most commonly reported plant-parasitic nematodes associated with A. squamosa at Rizal were Criconemoides, Meloidogyne, and Rotylenchulus. Among these, Criconemoides had the highest number which was followed by Meloidogyne and Rotylenchulus. The collected soil samples have an acidic soil which can be affected by the properties and contents of the soil itself such as the moderately low nitrogen, high phosphorus, sufficient potassium, and the texture of the soil itself, which is heavy. The temperature, concentration of NPK, and the texture of the soil samples showed a relation to the occurrence and count of the plant-parasitic nematodes associated with the A. squamosa. These factors serve as a limiting factor to the reproduction and penetrating ability of these plant-parasitic nematodes.

Further studies on its morphological characteristics using high standard equipment is recommended as well as sampling from different locations must be done. Molecular assessment is also recommended for the PPN's to be identified up to their specific epithet. Since this is the preliminary study in the identification of plant parasitic nematodes associated with A. squamosa, further detailed analysis and research on this could be a great advancement in the field of Nematology and Plant Pathology in the Philippines.

\section{Acknowledgment}

The authors are grateful to Asst Prof. Romnick A. Latina of Plant Pathology Department at University of the Philippines, Los Baños, Laguna, their consultant in the study, and for letting them use the Nematology Laboratory in UPLB. They are also grateful to the Commission on Higher Education CHED-DARETO K to 12 Transition Program Cycle II for funding the project.

\section{Conflict Of Interest}

Authors would hereby like to declare that there is no conflict of interests that could possibly arise.

\section{References}

Abawi GS, Gugino BK (2007) Soil Sampling for Plant Parasitic Nematode Assessment. Cornell University. New York State Agricultural Experiment Station. Available at http://hdl.handle.net/1813/43284, accessed on 18 February 2019.

Bellafiore S, Jougla C, Chapuis É, Besnard G, Suong M, Vu PN, De Waele D, Gantet P, Thi XN (2015) Intraspecific variability of the facultative meiotic parthenogenetic root-knot nematode (Meloidogyne graminicola) from rice fields in Vietnam. Académiedes Sciences 338:471-83.

Carating RB, Galanta RG, Bacatio CD (2014) The Soils of the Philippines. Bureau of Soils and Water Management. World Soils Book Series, Springer Science + Media Dondrecht 2014.DOI: 10.1007/978-94-017-8682-9-1.

Carpio JP, Delas Alas TP, Furio RC, Lascano MJ, Madredijo MJ, Magat CR, Miguello LG, Ocampo RJ, Ruiz KJ, Valderama CJ (2017) Alkalinity of Soil Samples from Three Selected Areas in Rizal Province, Philippines in Relation to different Variables . 2017 Cebu International Conference on Agricultural, Chemical, Biological and Environmental Sciences (ACBES-17) January 2627, 2017, Cebu (Philippines). Available at http://uruae.org/siteadmin/upload/DIR0117203.pdf, accessed on February 18, 2019.

Chalanska A, Labanowski G (2014) The Effect of Edaphic Factors on the Similarity of Parasitic Nematodes in the Soil Sampled in Nurseries of Ornamental Trees and Shrubs. Journal of Horticultural Research 22: 21-28.

Coyne DL, Nicol JM, Claudius-Cole B (2007) Practical Plant Nematology: A field and laboratory guide. SP-IPM Secretariat, International Institute of Tropical Agriculture (IITA), Cotonou, Benin.

Eisenback J (2002) Identification Guides for the Most Common Genera of Plant- Parasitic Nematodes. Mactode Publications, Blacksburg, Virginia, USA.

Ferris H, McKenry MV, Jaffee BA, Anderson CE, Juurma A (2004) Population Characteristics and Dosage Trajectory Analysis for Mesocriconemaxenoplax in California Prunus Orchards. Journal of Nematology 36(4):505-516.

Hoffmann JK (1973) Ecology and morphology of Criconema and Criconemoides Retrospective Thesis and Dissertations. 5087.

Hunt DJ, Luc M, Manzanilla-Lopez RH(2005). Identification, morphology and biology of plant parasitic nematodes. In: Luc M, Sikora RA, Bridge J (Eds.) Plant Parasitic Nematodes in Subtropical and Tropical Agriculture, 2nd edition, CABI, Wallingfor, United Kindom, Pp. 11-52..

Jaffee BA, Gaspard JT, Ferris H (1989) Density-Dependent Parasitism of the Soil-Borne Nematode Criconemella xenoplax by the Nematophagous Fungus Hirsutellar hossiliensis. Microbial Ecology17: 193-200.

Lamb JA, Fernandez FG, Kaiser DE (2014) Understanding Nitrogen in Soils. University of Minnesota. Extension, St Paul, Minnessota, USA 2014. 
Liu E, Yan C, Mei X, Zhang Y, Fan T (2013) Long-Term Effect of Manure and Fertilizer on Soil Organic Carbon Pools in Dryland Farming in Northwest China. PLoS One 8(2):e56536.

Luc M, Sikora RA, Bridge J (2005) Plant Parasitic Nematodes in Subtropical and Tropical Agriculture (2nd Edition), Cabi Publishing, Wallingford, United Kingdom.

Mengistu T, Dababat A, Sekora N, Akyazi F, Abebe E (2013) Identification key for agriculturally important plant-parasitic nematodes: A manual for nematology. International Maize and Improvement Center, Eskesehir, Turkey.

Miller PM (1980) Reproduction and survival of Xiphinema americanum on selected woody plants, crops, and weeds. Plant Disease 174-175.

Nakasano K (2004) Studies on Morphological and PhysioEcological Variations of the Reniform Nematode, Rotylenchulus reniformis Linford and Oliveira, 1940 with an Emphasis on Differential Geographical Distribution of Amphimictic and Parthenogenetic Populations in Japan. Journal of Nematology 36(3):356-420.

Nambiar L, Wainer J (2011) Collecting Soil and Plant Samples for Nematode Analysis. Agriculture Note AG1444. Department of Primary Industries, Victoria. Available at http://agriculture.vic.gov.au/agriculture/pests-diseases-andweeds/pest-insects-and-mites/foliar-nematodes-of-strawberryplants, accessed on February 18, 2019.

Narwade D, Aher A (2019) A Review on: Phytochemical and Pharmacological Study of Annona Squamosa. Pharma Tutor 7 (1): 5-10. DOI:https://doi.org/10.29161/PT.v7.i1.2019.5.

Needelman BA (2013) What are Soils? Nature of Edition Knowledge. Available at https://www.nature.com/scitable/knowledge/library/what-are-soils67647639, accessed on February 18, 2020.

Olson M, Harris T, Higgins R, Mullin P, Powers K, Olson S, Powers T (2017) Species Delimitation and Description of Meso criconema nebraskense $\mathrm{n}$. sp. (Nematoda: Criconematidae), a Morphologically Cryptic, Parthenogenetic Species from North American Grasslands. Journal of Nematology 49(1):42-66.

Pouyat RV, Yesilonisa ID, Russel-Anellib J, Neerchal NK (2007)
Soil Chemical and Physical Properties That Differentiate Urban Land-Use and Cover Types. Soil Science Society. Soil Science of America Journal 71(3): 1010-1019.

Regalado RG, Dela Cruz JC (2016) Soil pH and nutrient (Nitrogen, Phosphorus and Potassium) analyzer using colorimetry. Conference: TENCON 2016 - 2016 IEEE Region 10 Conference. DOI: $10.1109 /$ TENCON.2016.7848458.

Saha R (2011) Pharmacognosy and pharmacology of Annonasquamosa: A review. International Journal of Pharmacy \& Life Sciences 2(10): 1183-1189.

Sharma A, Goray NPVd (2009) Pharmacognostical studies on the leaf of Annona squamosa Linn. Pharmacognosy Journal 1:88-93.

Stack LB (2016) Soil and Plant Nutrition: A Gardener's Perspective. Available at https://extension.umaine.edu/gardening/manual/soils/soil-andplant-nutrition/ access on $25^{\text {th }}$ April, 2020.

Subbotin SA, Vovlas N, Yeates GW, Hallmann J, Kiewnick S, Chizhov VN, Manzanilla-Lopez, RH, Inserra RN, Castillo P (2015) Morphological and molecular characterization of Helicotylenchus pseudorobustus (Steiner, 1914) Golden, 1956 and related species (Tylenchida: Hoplolaimidae) with a phylogeny of the genus. Journal of Nematology 17: 27-52.

Tian B, Yang J, Zhang K (2007)Bacteria used in the biological control of plant- parasitic nematodes: populations, mechanisms of action, and future prospects. FEMS Microbiology Ecology 61(2): 197-213

Warner F (2009) Soil fertility, pH, texture and nematodes. Michigan State University. Available at http://msue.anr.msu.edu/news/soil_fertility_ph_texture_and_nemat odes accessed on February 18, 2019.

Xavier-Mis D (2016). Plant-Parasitic Nematodes in Corn. The LSU AgCenter and the LSUCollegeofAgriculture. Available at https://www.lsuagcenter.com/profiles/coverstreet/articles/plantparasitic\%20nematodes\%20in\%20corn accessed on February 2019.

Zehr EI, Lewis SA, Bonner MJ (1986) Some herbaceous hosts of the ring nematode (Criconemell axenoplax). Plant Disease 70:1066-1069. 